\title{
A Systematic Approach on Highly Potent Pathogens
}

\section{Vishal Bundele*}

Executive Engineer, Process at Elomatic Pharmalab Consulting \& Engineering Pvt Ltd in Mumbai, India

\section{Introduction}

The need for the contained handling and processing of pharmaceutical materials and pathogens is on the rise due to the increased focus on health and safety and the growing interest in the development of High Potency Active Pharmaceutical Ingredients (HPAPIs). A wide range of containment equipment is available on the market to meet the processing and operational needs of development and manufacturing. Selecting suitable equipment, however, requires an in-depth understanding of containment aspects in order to avoid operational hazards and large capital investments resulting from an 'oversizing' approach.

In containment equipment selection the focus is on preventing the personnel from being exposed to hazardous substances. The equipment can-not, however, fully prevents exposure. It is thus important to ensure that expo-sure through containment equipment over the operational course of time is less than the product/pharmaceutical material exposure limit. The selection of suitable containment equipment requires a thorough understanding of product and equipment related exposure limits.

\section{Product Exposure Limit}

The product exposure limit is defined in terms of the occupational expo-sure limit (OEL), which is calculated based on the No Observable Effect Level (NOEL). The NOEL value is obtained by testing the pharmaceutical material on the species with daily dos-age increases until the observable effect or reaction can be seen. The OEL can thus be calculated with the following formula:

$$
\begin{aligned}
& S T T W A_{\text {required }}=\frac{O E L \times 32}{N o C \times D F} \\
& O E L=\frac{N O E L \times B W}{V \times S F I \times S F 2}
\end{aligned}
$$

OEL: Occupational exposure limit NOEL: No Observable Effect Level BW: Body weight of the humans

$\mathrm{V}$ : Volume of breath per human per day (8-10 $\mathrm{m}^{3} / 8$-hour of shift)

SF1 and SF2: Safety factors for establishing a correlation between species and individuals if data for the humans is not available.

\section{Equipment Exposure Limit}

The exposure limit of the equipment can only be determined through air sampling procedures and then analysing the collected airborne particle samples. This amount is then divided by the volume of air sampled and the sampling time to give the Time Weighted Average (TWA) values of the exposure limit.

The TWA for evaluating pharmaceutical material is defined for 15 min as the Short Term Time Weighted Average (STTWA) and for 8 hours as the Long Term Time Weighted Average (LTTWA) (Figure 1).

\section{Correlation Between OEL and TWA}

Containment equipment needs be de-signed or selected in order to achieve LTTWA < OEL. The LTTWA can also be obtained from the STTWA considering the actual exposure time in the operational shifts. For example, the general industrial shift duration is 8 hours and the STTWA values for an exposure time of $15 \mathrm{~min}$ are available, then LTTWA based on STTWA can be calculated as follows.

$$
L T T W A=\frac{S T T W A}{32} \times N o C \times D F
$$

TWA: Time Weighted Average

LTTWA: Long Term TWA

STTWA: Short Term TWA

NoC: Number of cycles

DF: Dilution Factor

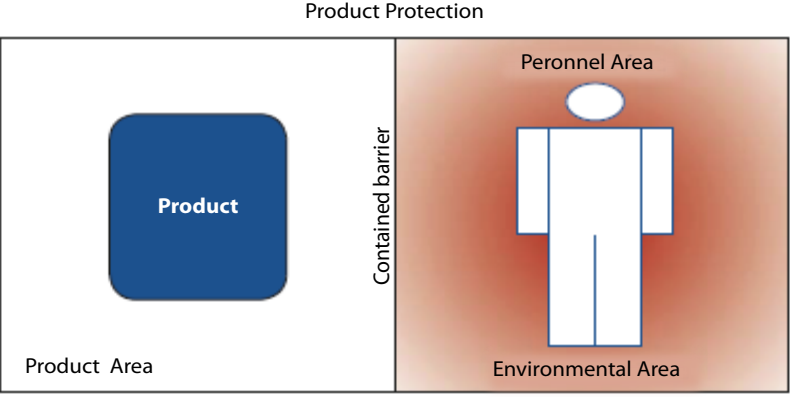

Personnel/Environmental Protection

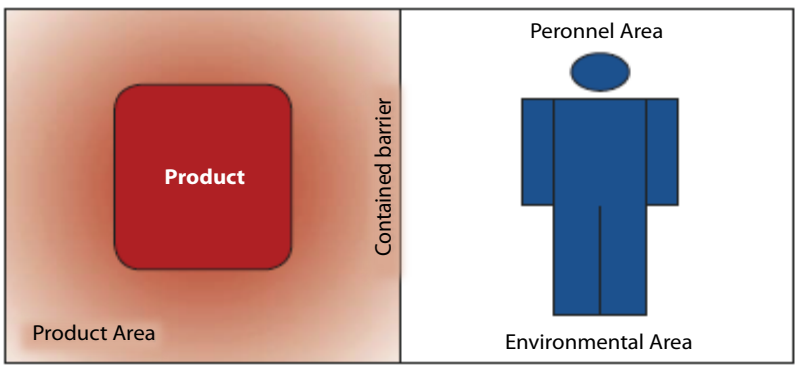

Figure 1: Containment is the isolation of a product or pharmaceutical materials from personnel and the environment or vice versa with the use of a physical barrier.

${ }^{*}$ Corresponding author: Vishal Bundele, Executive Engineer, Process a Elomatic Pharmalab Consulting \& Engineering Pvt Ltd in Mumbai, India, Tel: 91-9324036715; E-mail: vishal.bundele@elomatic.com

Received July 24, 2014; Accepted July 29, 2014; Published August 04, 2014

Citation: Bundele V (2014) A Systematic Approach on Highly Potent Pathogens. J Bioprocess Biotech 4: 172 doi: 10.4172/2155-9821.1000172

Copyright: @ 2014 Bundele V. This is an open-access article distributed under the terms of the Creative Commons Attribution License, which permits unrestricted use, distribution, and reproduction in any medium, provided the original author and source are credited. 


\begin{tabular}{|c|c|c|c|c|}
\hline Particulars & Down Flow Booths & $\begin{array}{l}\text { High Containment } \\
\text { Screens }\end{array}$ & $\begin{array}{l}\text { Restricted Barrier Access Systems } \\
\text { (RABS) }\end{array}$ & Barrier Isolators \\
\hline Flow direction & $\begin{array}{l}\text { Unidirectional flow } \\
\text { through ceiling HEPA }\end{array}$ & NA & $\begin{array}{l}\text { Flow through clean room air circulation } \\
\text { system or dedicated air filtration and } \\
\text { conditioning system }\end{array}$ & $\begin{array}{l}\text { Uncompromised continuous flow through } \\
\text { supply and return HEPA of dedicated air } \\
\text { filtration and conditioning system }\end{array}$ \\
\hline OEL levels of material handled & Highest & High & Moderate & Least \\
\hline Health Hazard level & Mild & Moderate & High & Severe \\
\hline Level of Isolation & Least & Moderate & High & Highest \\
\hline Level of Automation & Least & NA & High & Highest \\
\hline \multirow[b]{2}{*}{ Application } & $\begin{array}{l}\text { Effective protection } \\
\text { when handling dusty } \\
\text { material. }\end{array}$ & $\begin{array}{l}\text { Effective way of } \\
\text { boasting down flow } \\
\text { booth capabilities. }\end{array}$ & $\begin{array}{l}\text { Physical barrier between operators and } \\
\text { production areas but barrier is limited. }\end{array}$ & $\begin{array}{l}\text { Uncompromised continuous isolation } \\
\text { of its interior and external environment, } \\
\text { including surrounding clean room and } \\
\text { personnel. }\end{array}$ \\
\hline & $\begin{array}{l}\text { Air flow carries the } \\
\text { material away from the } \\
\text { breathing zone of the } \\
\text { operator into the low } \\
\text { exhaust grill. }\end{array}$ & $\begin{array}{l}\text { Effective solution } \\
\text { for air suits due } \\
\text { to operational } \\
\text { constraints. }\end{array}$ & $\begin{array}{l}\text { System's interior atmosphere can be } \\
\text { controlled however pressure control is } \\
\text { limited. }\end{array}$ & $\begin{array}{l}\text { Effective pressure control in the interior of } \\
\text { the system. }\end{array}$ \\
\hline $\begin{array}{l}\text { Classification NA: Not Applicable } \\
\text { HEPA: High Efficiency Particulate } \\
\text { Filter }\end{array}$ & $\begin{array}{l}\text { Recirculatory Booths } \\
\text { Once Through Booths }\end{array}$ & NA & $\begin{array}{l}\text { Passive Open RABS Active Open RABS } \\
\text { Passive Closed RABS Active Closed } \\
\text { RABS }\end{array}$ & Positive Isolator; Negative Isolator \\
\hline
\end{tabular}

Table 1: Isolation methods.

A factor of 32 is used as there are four cycles of 15 minutes in an hour and the dilution factors is available data for STTWA for a $100 \%$ concentration of pharmaceutical material.

The containment equipment should as such be selected so that LTTWA is lower than the product-specific OEL.

\section{Equipment Evaluation}

The selected equipment can be evaluated by considering a worst case scenario where LTTWA = OEL and then calculating the STTWA from the aforementioned formula as follows:

$$
S T T W A_{\text {required }}=\frac{O E L \times 32}{N o C \times D F}
$$

TWA: Time Weighted Average

\section{STTWA: Short Term TWA}

NoC: Number of cycles

\section{DF: Dilution Factor}

The containment equipment can then be physically tested through appro-priate methods to evaluate the following:

$$
\text { STTWA }<\text { STTWA }_{\text {required }}
$$

\section{Methods of Isolation and Selection}

As indicated earlier the OEL of pharmaceutical materials is the basis for the selection of the containment level required for processing the material. Thus, as the OEL limit shows a tendency towards lower values a more sophisticated level of isolation is required to carry out the safe processing of the pharmaceutical material.

The different types of isolation methods available are provided in Table 1. The appropriate isolation method is selected based on the criticality of the material handled or processed. In essence it is based on the OEL, the physical characteristics of the materials, the quantity handled and the duration of pharmaceutical material processing (Figure 2).

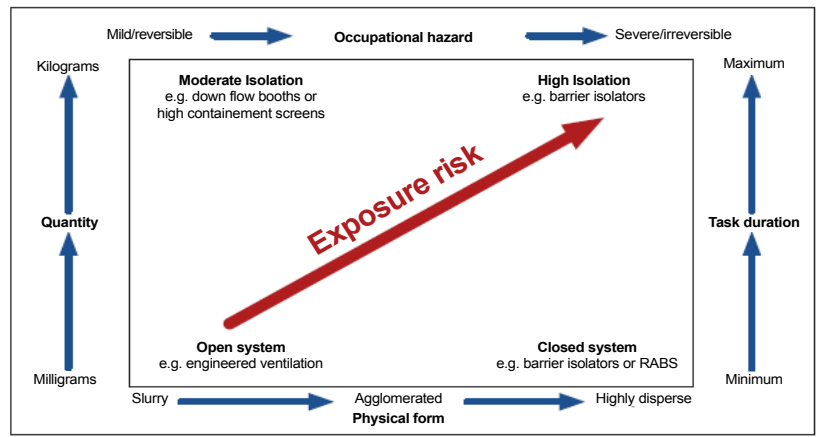

Figure 2: The appropriate containment system for each process is based on the quantity of materials, the occupation health hazard posed, the duration of the task and the physical form the handled materials.

\section{Proper Selection and Meeting Owner's Requirements}

HPAPI is currently one of the fastest growing segments in the pharmaceutical industry, with a growth rate of 8 to 10 per cent. This high growth rate is attributed to their application in the formulation of high potent drugs used to combat some of the severest dis-eases. The market opportunities and treatment capabilities have resulted in the increased interest shown by pharmaceutical companies in investing in the development and manufacturing of HPAPI.

Handling these materials, however, requires sophisticated isolation methods, which demands an understanding of the basic concepts of containment engineering. This understanding assists in the proper selection of the suitable isolation method thereby meeting the operational and financial requirements of the owner. 